\title{
chapter UK Deinstitutionalisation: Neoliberal Values and Mental Health
}

\author{
Andrew Scull
}

\section{Introduction}

The year 2021 marks the sixtieth anniversary of Enoch Powell's Water Tower speech a famous or infamous occasion depending upon one's assessment of deinstitutionalisation and the advent of community care. Powell, the minister of health in Harold Macmillan's Tory government, was a superb orator and a man not known to mince his words. In 1968, his 'Rivers of Blood' speech on immigration would cost him his position on the Opposition front bench and essentially end his political career (see also Chapters 1 and 2). In 1961, however, he was seen as a formidable figure in the Conservative Party and a possible future prime minister. Delivered at the annual conference of the National Association for Mental Health, the Water Tower speech announced a radical shift in mental health policy. Since the passage of the Asylums Act in 1845, which made construction of county lunatic asylums at taxpayer expense compulsory, Britain, like the rest of the Western world, had placed primary emphasis on institutionalisation as the preferred solution to the problems posed by serious mental illness. That era, Powell announced, was coming to a close. ${ }^{1}$

\section{Neoliberal Dawn}

The shift in policy was couched in the apocalyptic tones that Powell preferred. 'There they stand,' he intoned, 'isolated, majestic, imperious, brooded over by the gigantic water-tower and chimney combined, rising unmistakable and daunting out of the countryside - the asylums our forefathers built with such immense solidity to express the notions of their day. Do not for a moment underestimate their powers of resistance to our assault.' Yet assault them he would. The government's plans 'imply nothing less than the elimination of by far the greatest part of this country's mental hospitals'. It was, he acknowledged, 'a colossal undertaking'. Within fifteen years, however, half of the existing beds, 75,000, should be gone: 'if we are to have the courage of our ambitions, we ought to pitch the estimate lower still, as low as we dare, perhaps lower.' Mistakes might be made, but 'if we err, it is our duty to err on the side of ruthlessness. For the great majority of these establishments there is no, repeat no, appropriate future use.'

Powell granted that vast sums had been spent on these edifices, and in the past decade much treasure had been expended to make them 'less inadequate'. Those sunk costs were proffered as one argument against radical change. Other objections could be expected from the 'hundreds of men and women who have given years, even lifetimes, to the service of a mental hospital or group of hospitals ... have laboured devotedly, through years of scarcity and neglect, to render conditions in them more tolerable'. Too bad. The mental hospitals were 'doomed'; and Powell volunteered to be 'the first to set the torch to the 
funeral pyre'. In the following year, the NHS Hospital Plan began the process of enacting these proposals.

Powell spoke like an Old Testament prophet, and a prophet he proved to be. Though the asylums did not begin to vanish from the scene until the 1980s under Margaret Thatcher, their population did shrink significantly throughout the 1960s and 1970s. On an average day in 1960, the population of England's mental hospitals was just over 140,000. By 1970, the census had fallen to 106,000 and, a decade later, to just over 79,000. Under administrations of all political stripes, Conservative, Labour and Coalition, the remorseless run down of institutional populations has continued apace. When David Cameron took power in 2010, the inpatient population had fallen to less than 23,000; and, while most mental hospitals remained open into the 1980s, notwithstanding the shrinking inpatient population, during the second half of Thatcher's term in office they were largely abandoned. Some, like the massive Friern Hospital in north London, were converted to upscale flats for the nouveau riche (the building's past coyly hidden as it became the Princess Park Manor); while others, like the old Devon County Asylum at Exeter, contaminated with asbestos and heavy metals, proved too costly to repurpose and were left to rot. 'For dust thou art, and into dust shalt return', as one of Powell's favourite books would have it.

As Powell's speech should make clear, deinstitutionalisation was no accident. It was a consciously chosen policy, pursued relentlessly over many decades, even as evidence materialised that the alternative to the hospital - 'community care' - was largely a figment of politicians' imaginations, a phrase that sought to obscure the fact that there was little in the way of community to which most mental patients could return and still less in the way of care. Community care is, as I have suggested elsewhere, a shell game in which there is no pea. ${ }^{2}$ Those suffering from serious forms of mental illness have been cast into the wilderness - a wilderness that has little time for those with few resources of their own; for people who lack the capacity to function in a neoliberal environment whose architects regard them as little more than a drain on the public purse; and for 'unfortunate creatures' chronically dependent on the not-so-tender mercies of a shrinking welfare state, doubly stigmatised for their illness and because they show no signs of reform or recovery.

Psychiatrists have embraced the myth that the mass discharges of patients reflected advances in therapeutics, most especially the psychopharmacological revolution that began in 1954, with the marketing of Largactil (chlorpromazine). That, coincidentally, is the year in which the mental hospital census in England and Wales reached its zenith. The reality, however, is that the number of patients resident in many hospitals had begun to decline several years before antipsychotics arrived on the scene. Leading British psychiatrists such as Sir Aubrey Lewis and Michael Shepherd were rightly sceptical about the relationship between pharmacology and hospital discharges, and a host of later scholarship has confirmed their suspicions (see also Chapter 2 ). ${ }^{3}$ Drugs may have soothed professional anxieties when psychiatrists were asked to discharge long-stay patients, and the effects of Thorazine (chlorpromazine) and its copycat drugs on florid symptomatology may have made a difference at the margin, notwithstanding the tendency of disturbed patients to be noncompliant about taking their medications. Most awkwardly, though, for the advocates of the notion of a technological fix as the source of deinstitutionalisation, they have no way of accounting for the pattern of accelerated discharge that manifested itself from the 1970s onwards, a period where no breakthroughs in psychopharmacology materialised.

The record demonstrates that it was policy choices, not drugs, that fundamentally underpinned deinstitutionalisation, whose impetus did not come from the ranks of 
psychiatry. Indeed, the shift from the hospital to the community occurred largely behind the backs of the profession and independent of its predilections and actions. Political preferences ruled and, by and large, the profession followed along.

Deinstitutionalisation was not a uniquely British phenomenon, of course. Strikingly similar patterns can be observed in the United States and, later, in most advanced industrial societies. The mental hospital, once touted as 'the most blessed manifestation of true civilization the world can present', ${ }^{4}$ was now dismissed as a 'total Institution' on a par with such places as prisons and concentration camps, an anti-therapeutic engine of degradation that fomented chronicity rather than cured its inmates. ${ }^{5}$ That focus on the defects of the institution and its malign effects on those it purported to treat accounted for much of the support the new policy drew from civil libertarians and those concerned with patients' rights (see also Chapters 3, 4, 13 and 20). Yet it substituted for careful assessment of what alternatives were being prepared, if any, for those discharged back into society at large.

Long before the principle that medical care would be provided free and as a right for all British citizens had been established, the special problems associated with serious mental illness had prompted the state to pay for the confinement and treatment of the overwhelming majority of mental patients. Such care, well into the twentieth century, had come at the price of being labelled a 'pauper lunatic', but the costs of housing and providing for the tens of thousands of patients who crowded the wards had long constituted a major draw on the public purse. Nor did that change much with the advent of the NHS in 1948. Mental hospitals continued to exist as a separate system, independent of the health service that dealt with physical ill health. The end of that separation was forecast in the 1962 Hospital Plan but only became a reality during the 1970s. No longer were the mental health services a separate administrative and financial system, and in the fight for resources, the generally low priority placed on mental illness has left the advocates for resources in a parlous position. Worse still, the incurable tendency of the political classes to reorganise and 'reform' the health services has repeatedly added to the chaos. Particularly pernicious in this regard was the 1990 National Health and Community Care Act, which passed responsibility for community care on to local authorities. Uneven and inadequate provision has been the inevitable result. No resources were allocated to the local authorities to provide for these new responsibilities, and the dislocations associated with establishment of NHS Trusts then compounded the problem (see also Chapters 10 and 30).

\section{Neoliberal Supremacy}

The 1970s saw the breakdown of the post-war consensus in British politics, which had seen both parties embrace a strong role for the government in the economy, an expanded welfare state and a major role for trade unions. ${ }^{6}$ Though they would be exacerbated by the external shock of the sharp rise in oil prices in 1973, the structural problems that already plagued the economy were exacerbated even further by the increasingly fractious state of labour relations. Unions flexed their power. Massive strikes, both official and unofficial, appeared to render Britain almost ungovernable. The country's difficulties were made worse by the weakness and fecklessness of the politicians of both parties who ruled Britain during this decade. ${ }^{7}$ The miners' strikes of 1972 and 1974, and the resultant blackouts and forced move to a three-day work week, brought the collapse of the Heath government, but Labour under Callaghan proved equally inept and incompetent in the face of industrial turmoil and political unrest. The 'Winter of Discontent' of 1978/9 saw more massive strikes, particularly 
by public sector trade unions, as Callaghan vainly sought to rein in rampant inflation. Bodies went unburied, rubbish uncollected and flying pickets restricted hospitals to taking emergency patients only. Public services appeared to be on the brink of collapse, as did the economy itself.

The sick man of Europe responded by electing a Conservative Party led by Margaret Thatcher in May 1979. Blessed with a thumping majority, her pro-market and neoliberal instincts, and visceral hostility to both unions and the public sector, would dominate British politics for decades. Within two years, she had ejected most of the one-nation Tories from her government and embarked on a radical reconstruction of the British economy and the British state. By the time Tony Blair brought 'New Labour' out of the political wilderness and back into power, following more than a decade and a half of Conservative rule, trade unions had been neutered as a political force, economic inequality had widened sharply and the parameters of political discourse and public policy had been altered, if not permanently, then certainly for the foreseeable future. Blair's 'Brave New Britain' in many ways continued to embrace key plans of Thatcherite orthodoxy, albeit while putting a softer, more emollient face on its policies. ${ }^{8}$

Someone who could announce with a straight face (and meaning it) that 'there is no such thing as society', and who proceeded to amplify her meaning by insisting that 'It is our duty to look after ourselves', was not inclined to show much support for those who depended upon public provision of services for their very survival. Scornfully, in the same interview Thatcher noted that 'we have gone through a period when too many children and people have been given to understand "I have a problem, it is the Government's job to cope with it!" ... they are casting their problems on society." It was a view for which she evinced no sympathy. At best, she saw a role for Victorian charity, de haut en bas: 'There is a living tapestry of men and women and people [sic] and the beauty of that tapestry and the quality of our lives will depend upon how much each of us is prepared to take responsibility for ourselves and each of us prepared to turn round and help by our own efforts those who are unfortunate.' Victims of misfortune who sought collective, public responses to the difficulties they confronted were out of luck. Hers was not an administration who viewed such supplicants with favour. Handouts were to be in short supply.

In Thatcher's view, British citizens had become far too dependent on the state, losing their sense of responsibility for their own lives. For her, the key to reviving Britain was to restore economic incentives and the discipline of the marketplace, rolling back the frontiers of the state and reducing expenditure on welfare, confining it to those in 'real need'. Social security payments steadily eroded in value, and sickness and unemployment benefits were cut. The upshot was a doubling of the relative poverty level by the time she resigned in 1990, when 28 per cent of British children were found to be living below the poverty line (3.3 million, up from 1.7 million when she took office) - statistics that grew even worse under her successor, John Major. Levels of inequality showed no signs of declining under New Labour and have worsened still further since. ${ }^{10}$ Neoliberalism, in other words privatisation, the deification of individualism, the destruction of union power, economic liberalisation and increased ideological hostility to the collective provision of public goods became the hallmarks of her tenure in office and have perceptibly changed the terms of political debate ever since. Welfare 'reform', in Britain as in the United States, has become a term of art disguising repeated assaults on the social safety net and the demonisation of those dependent upon it. 


\section{Neoliberal NHS and Mental Health Services}

The sole and singular exception to this sustained ideological attack on the welfare state in the UK has been the NHS. Thatcher ostentatiously chose private health care, but this is one area where her ideology encountered stiff resistance (see also Chapter 9). At least at the level of rhetoric, governments of all stripes since she was forced from office have genuflected to the NHS and promised to protect it, a reflection of its overwhelming popularity among the public at large. Under Labour, the rhetoric was matched for a time with an attempt to boost resources for the health services, though little of this new money found its way into the mental health sector. The promised 'parity of esteem' for physical and mental health remained a slogan without substance. The great bulk of the additional money provided to the NHS was directed at physical illness, though administrative obfuscation and the fragmentation of service provision have made quantifying where the money went extraordinarily difficult. ${ }^{11}$ Moreover, though serious violence among those living with schizophrenia and psychosis is quite rare, ${ }^{12}$ media-inspired moral panics surrounding this issue have exercised a lopsided influence over public policy and have meant that such increases in resources for mental health provision as did occur under Labour were disproportionately spent on mitigating these risks - a distortion of policy that found legislative recognition in the new category of 'Dangerously Severe Personality Disorder' (DSPD) in the 2007 Mental Health Act (see also Chapters 23, 27 and 28). Labour's decision to have the NHS Trusts mimic the marketplace, a standard feature of neoliberal policy, added additional layers of administration and increased the strain on the system, to no good effect.

Whatever slight progress towards improving the lot of the seriously mentally ill that had accompanied Labour's thirteen years in power has since been reversed. David Cameron had given notice prior to wining the general election and entering a coalition with the Liberal Democrats in 2010 that 'the age of irresponsibility was going to be giving way to the age of austerity'. With the enthusiastic support of his chancellor, George Osborne, he was as good as his word. The transfer of welfare to the private and voluntary sectors - a key part of the Thatcherite agenda - was soon under way. Over the ensuing decade, local authorities had their funding from Whitehall cut by 60 per cent. At the same time, caps were introduced on increases in council tax, placing local government under increasing fiscal strain. Under the 1990 legislation, local authorities bore primary responsibility for the community care of the mentally ill. What meagre provision they had previously made for their needs was increasingly threatened. Simultaneously, sharp cuts of the social care budget and the essential abandonment of any pretence to provide social housing worsened the situation further. Nor were these to be temporary measures to cope with the economic shock of the Great Recession. That provided the initial excuse for the cuts, but by 2013 (by which time public spending had already been cut by 14.3 billion pounds compared to 2009-10), Cameron announced that he had no intention of reversing the changes when and if the economy improved. The reduced commitment of the state was to be a permanent feature of Britain's future.

The NHS was supposedly to be protected from austerity; its funding 'ring-fenced'. Though this was true in nominal terms particularly as demands increased with the ageing of the population, the health service has suffered drastic cuts in real terms. Cash increases that averaged 1.4 per cent per year adjusted for inflation were entirely inadequate to meet demand. Forced to prioritise day-to-day expenditures, capital budgets were neglected, which led to rapid deterioration of both buildings and equipment. Over 32,000 overnight 
beds were lost in a decade. Waiting times for services of all sorts lengthened, despite promises to reduce them. And, as usual, in the face of this deteriorating fiscal environment, mental health care suffered disproportionately. The gap between needs and services available took another turn for the worse, and deeper cuts in social services added to the problems faced by those with serious mental illness.

The idea that we bear a collective moral responsibility to provide for the unfortunate indeed, that one of the marks of a civilised society is its determination to provide as of right certain minimum standards of living for all its citizens - has been steadily eroding since Thatcher came to power. In its place, we have seen the resurgence of an ideology far more congenial and comforting to the privileged: the myth of the benevolent 'Invisible Hand' of the marketplace, and its corollary, an unabashed moral individualism. There is little place (and less sympathy) within such a worldview for those who are excluded from the race for material well-being by chronic disabilities and handicaps - whether physical or mental disease, or the more diffuse but cumulatively devastating penalties accruing to those belonging to racial minorities or living in dire poverty.

The punitive sentiments directed against those who must feed from the public trough extend only too easily to embrace those who suffer from the most severe forms of psychiatric misery. Those who seek to protect the long-term mental patient from the opprobrium visited upon the welfare recipient may do so by arguing that the patient is both dependent and sick. But I fear this approach has only a limited chance of success (see also Chapter 27). After all, despite two centuries of propaganda, the public still resists the straightforward equation of mental and physical illness. Moreover, the long-term mental patient in many instances will not get better, and often fails to collaborate with his or her therapist to seek recovery. Such blatant violations of the norms governing access to the sick role in our societies make it unlikely that people with severe and enduring mental ill-health will be extended the courtesies and exemptions accorded to the conventionally sick (see also Chapter 3$).{ }^{13}$ Instead, even those incapacitated by psychiatric disability all too often find themselves the targets of those who would abolish social programmes because they consider any social dependency immoral.

\section{Conclusion}

Seen in this larger context, the neglect that has been the hallmark of the shift from the asylum to community care should come as no surprise. Among those with more noticeable continuing impairment, ex-patients placed with their families seem overall to have fared best. It would be a serious mistake, though, to suppose that even here deinstitutionalisation has proceeded smoothly and has proved unambiguously beneficial. Quite early in the process, John Wing expressed 'surprise' that, in view of the greatly increased likelihood of someone with schizophrenia living at home instead of in a hospital, so little research was being done on the problems experienced by their relatives. ${ }^{14}$ His own work, and that of his associates demonstrated that 'the burden on relatives and the community was rarely negligible, and in some cases, it was intolerable' (see also Chapter 2) ${ }^{15} \mathrm{~A}$ good deal of the distress and misery continues to remain hidden because of families' reticence about complaining, a natural tendency, but one which has helped to sustain a false optimism about the effects of the shifts to community treatment. As George Brown pointed out, 'relatives are not in a strong position to complain - they are not experts, they may be ashamed to talk about their problems and they have come to the conclusion that no help can 
be offered which will substantially reduce their difficulties'. ${ }^{16}$ Such conclusions may have a strong factual basis, in view of the widespread inadequacies or even absence of after-care facilities, and the reluctance, often refusal, of the authorities to countenance rehospitalisation. Long delays in receiving appointments, the absence of any provision for respite care, and the lack of co-ordination among service providers compound the problems families face, and eventually many give up the struggle.

Many psychotic patients are thus left to shuffle between flop-houses, homelessness, and short periods in jail, when their illness and dependency cause them to commit what are usually minor offences. Misery and poverty remain their lot, till most of them succumb to an early death. Given the thrust of public policy for the past sixty years, it should come as no surprise to learn that those afflicted with serious mental illness have a life expectancy of between fifteen and twenty-five years less than the rest of us. ${ }^{17}$ It is, nonetheless, a disgrace.

\section{Key Summary Points}

- The number of patients resident in many hospitals had begun to decline several years before antipsychotics arrived on the scene.

- The population of asylums did shrink significantly throughout the 1960s and 1970s, though mental hospitals did not begin to vanish from the scene until the 1980s under Margaret Thatcher.

- Deinstitutionalisation was no accident. It was a consciously chosen neoliberal policy, pursued relentlessly over many decades.

- Welfare 'reform,' in Britain as in the United States, has become a term of art disguising repeated assaults on the social safety net and the demonisation of those dependent upon it.

- 'Community care' in the era of neoliberal politics has turned out to be an Orwellian euphemism, masking a nightmare existence for all too many of those afflicted with serious psychoses and for their families.

\section{Notes}

1. E. Powell, Address to the Mental Health Association, 1961. The Papers of Enoch Powell, GBR/0014/Poll. Churchill Archives Centre, Cambridge, Poll 4/1/1, 9/3/1961.

2. A. Scull, Decarceration: Community Treatment and the Deviant: A Radical View. Englewood Cliffs, NJ: Prentice-Hall, 1977.

3. P. Lerman, Deinstitutionalization and the Welfare State. New Brunswick, NJ: Rutgers University Press, 1982; W. Gronfein, Psychotropic drugs and the origins of deinstitutionalization. Social Problems (1985) 32: 437-53; S. Rose, Deciphering deinstitutionalization: Complexities in policy and program analysis. Milbank Memorial Fund Quarterly (1979) 57: 429-60; A. Scull, The decarceration of the mentally ill: A critical view. Politics and Society (1976) 6: 173-212.

4. G. Paget, The Harveian Oration. Cambridge: Deighton, Bell, 1866, pp. 34-5.

5. E. Goffman, Asylums: Essays on the Social Situation of Mental Patients and Other Inmates. New York: Doubleday, 1961.

6. K. O. Morgan, Britain in the seventies - our unfinest hour? French Journal of British Studies (2017) 22, https:// doi.org/10.4000/rfcb.1662.

7. D. Sandbrook, Seasons in the Sun: The Battle for Britain. London: Penguin Allen Lane, 2012. 
8. J. Gray, Blair's project in retrospect. International Affairs (2004) 80: 39-48.

9. M. Thatcher, Interview with Women's Own, 23 September 1987.

10. A. Shephard, Income inequality under the Labour government. Briefing Note No. 33. London: Institute for Fiscal Studies, 2003; C. J. Belfield, J. Cribb, A. Hood and R. Joyce, Living Standards, Poverty and Inequality in the UK, 2016. London: Institute for Fiscal Studies, 2016.

11. G. Thompson, NHS expenditure in England. Research Briefing SN/SG/724, 7. London: House of Commons Library, 2009.

12. S. Fazell, G. Gulati, L. Linsell, J. R. Geddes and M. Grann, Schizophrenia and violence: Systematic review and meta-analysis. PLoS Medicine (2009) 6: e1000120. https://doi.org/10.1371/journal.pmed.1000120.

13. T. Parsons, The Social System. New York: Free Press, 1951.

14. J. K. Wing, Planning and evaluating services for chronically handicapped psychiatric patients in the United Kingdom. In L. I. Stein and M. A. Test, eds, Alternatives to Mental Hospital Treatment. New York: Plenum Press, 1978.

15. J. K. Wing and G. W. Brown, Institutionalism and Schizophrenia. Cambridge: Cambridge University Press, 1970.

16. G. W. Brown, M. Bone, B. Dalison and J. K. Wing, Schizophrenia and Social Care. London: Oxford University Press, 1966.

17. S. Brown, Excess mortality of schizophrenia: A meta-analysis. British Journal of Psychiatry (1997) 171: 502-8; S. Saha, D. Dent and J. McGrath, A systematic review of mortality in schizophrenia: Is the mortality gap worsening over time?. Archives of General Psychiatry (2007) 64: 1123-31; T. M. Laursen, Life expectancy among persons with schizophrenia or bipolar affective disorder. Schizophrenia Research (2011) 131: 101-4; J. F. Hayes, L. Matson, K. Waters, M. King and D. Osborn, Mortality gap for people with bipolar disorder and schizophrenia: UK-based cohort study 2000-2014. British Journal of Psychiatry (2017) 211: 175-81. 
